\title{
Penerapan dan Pemanfaatan Teknologi Sistem Pakar Untuk Diagnosa Hama Dan Penyakit Jamur Tiram Pada Kelompok Tani Desa Dasan Borok Kabupaten Lombok Timur
}

\author{
Nurhidayati ${ }^{1^{*}}$, Aris Sudianto ${ }^{2}$, Suhartini ${ }^{3}$ \\ 1Program Studi Sistem Informasi, Universitas Hamzanwadi \\ 2,3Program Studi Teknik Informatika, Universitas Hamzanwadi \\ *hidayati2188@gmail.com
}

\begin{abstract}
Abstrak
Penerapan dan pemanfaatan teknologi saat ini sudah banyak terlihat hampir diberbagai bidang kehidupan manusia. Teknologi ini hadir untuk membantu serta memudahkan manusia dalam menyelesaikan pekerjaan dan mengatasi berbagai macam permasalahan yang rumit sekalipun contohnya dalam hal menganalisis seperti yang terjadi pada para petani dan kelompok pengusaha jamur tiram yang ada di Desa Dasan Borok Kecamatan Suralaga Lombok Timur. Seringnya terjadi kegagalan panen merupakan suatu permasalahan yang saat ini terjadi tiap kali panen datang, terjadinya hal ini menimbulkan kerugian bagi para petani dan harus segera ditangani dengan cepat dan tepat. Sistem pakar berbasis web merupakan solusi yang tepat untuk mengatasi permasalahan tersebut, dimana sistem ini bisa menjadi pusat informasi dan dijadikan sebagai alat dalam mengambil keputusan bagi para petani dan pengusaha jamur tiram untuk bisa mengetahui penyebab kerusakan dan mendeteksi jenis penyakit dan hama yang menyerang jamur tiram. Dengan diterapkannya sistem ini diharapkan mampu mengatasi atau mengurangi permasalahan para petani untuk meningkatkan hasil panen yang lebih baik dan maksimal.[1]
\end{abstract}

Kata kunci : Hama, Jamur Tiram, Sistem pakar, Web.

\begin{abstract}
Abstact
The application and use of technology today has been seen in almost every field of human life. This technology is here to help and facilitate humans in completing work and overcoming a variety of complex problems even for example in terms of analyzing as happened to the farmers and groups of oyster mushroom entrepreneurs in Dasan Borok Village, Suralaga District, East Lombok. The frequent occurrence of crop failure is a problem that currently occurs every time the harvest comes, this occurrence causes losses to farmers and must be dealt with quickly and appropriately. Web-based expert system is the right solution to overcome these problems, where this system can become an information center and be used as a tool in making decisions for farmers and entrepreneurs of oyster mushrooms to be able to determine the cause of damage and detect the types of diseases and pests that attack oyster mushrooms. With the implementation of this system it is expected to be able to overcome or reduce the problems of farmers to improve better and maximum yields.
\end{abstract}

Keyword : Expert system, Pests, oyster mushroom, web.

\section{Pendahuluan}

Perkembangan teknologi informasi telah membawa dampak yang signifikan dalam berbagai bidang. Hal ini mengakibatkan kemajuan pada perangkat lunak yang diimbangi dengan kecanggihannya.[2] Secara langsung ataupun tidak, teknologi informasi telah menjadi bagian penting untuk masyarakat dalam berbagai bidang kehidupan.[3]

Teknologi informasi hampir tidak dapat dipisahkan dari berbagai aspek kehidupan manusia. Oleh karena itu kecanggihan teknologi juga dimanfaatkan oleh para pembudidaya Jamur Tiram untuk mendapatkan informasi $x$ 
mengenai bisnisnya. Melalui media internet seseorang dapat mencari informasi yang dibutuhkan.[4] Sistem pakar untuk mendiagnosa hama dan penyakit pada tanaman Jamur Tiram dapat dijadikan informasi dan pedoman untuk mendeteksi hama dan penyakit yang muncul pada tanaman Jamur Tiram serta cara menanggulanginya.[5]

Sistem pakar merupakan sub bidang kecerdasan buatan, kecerdasan buatan merupakan kegiatan yang menyediakan mesin seperti komputer dengan kemampuan untuk menampilkan perilaku yang dianggap cerdas jika diamati oleh manusia. Konsep sistem pakar didasarkan pada asumsi bahwa pengetahuan pakar dapat disimpan dan diaplikasikan, kemudian diterapkan oleh orang lain saat dibutuhkan. [6]

Dengan mengimplementasikan sistem pakar ke dalam komputer yang dapat menghasilkan beberapa manfaat seperti keakurasian, kecepatan, dan dapat diakses kapanpun sehinga dapat meringankan tugas dari para pakar dibidangnya dan juga dapat digunakan untuk menentukan solusi yang tepat dari permasalahan yang ada. Manfaat penggunaan media teknologi disegala bidang memang menjadi hal yang tidak bisa dipandang sebelah mata, sebagai contoh penerapan media pembelajaran berbasis teknologi menjadi lebih baik dibanding dengan cara ceramah[7].

Jamur Tiram merupakan salah satu jenis Jamur yang saat ini menjadi alternatif pilihan sebagai makanan sehat yang layak dikonsumsi. Selain dapat dikonsumsi juga bernilai ekonomi tinggi.
Banyaknya masyarakat yang mengenal Jamur Tiram serta budidaya yang mudah dan efisien. Menjadikan Jamur Tiram menjadi pilihan bagi masyarakat sebagai makanan yang layak konsumsi. [8]

Dari hasil wawancara dan observasi lapangan diketahui banyak penanaman biji Jamur dalam sekali penanaman sebanyak 1.500 biji, akan tetapi dari 1.500 biji penanaman tersebut, dalam masa pertumbuhannya masih banyak yang mengalami kerusakan sehingga petani sering mengalami kegagalan panen hal itu disebabkan oleh berbagai macam jenis hama dan penyakit yang dijumpai dalam setiap tanaman, akan tetapi permasalahannya adalah apakah hama dan penyakit tersebut menimbulkan kerugian bagi para petani Jamur Tiram atau tidak, namun ini merupakan kendala yang paling sering dialami oleh para petani Jamur Tiram. Terjadinya kegagalan panen pada Jamur Tiram ini dipengaruhi oleh beberapa faktor utama yaitu : kondisi udara, air, tanah, serta bibit Jamur. Apabila kebersihan dalam proses budidaya Jamur kurang bagus, bisa dipastikan hama serta penyakit akan muncul dan mengganggu pertumbuhan Jamur Tiram .[8]

Sejalan dengan permasalahan yang ditemui oleh para petani Jamur Tiram, hal serupa juga dialami oleh kelompok usaha Jamur Tiram yang ada di desa Dasan Borok, Kecamatan Suralaga. Berdasarkan hasil wawancara yang diperolah, masalah yang sedang dihadapi oleh kelompok usaha Jamur tersebut diantaranya: banyaknya mengalami kerusakan dalam pertumbuhan 
Jamur, itu disebabkan oleh kondisi udara, air, tanah, serta bibit jamur juga. Apabila kebersihan dalam proses budidaya Jamur kurang bagus, bisa dipastikan berbagai macam hama serta penyakit akan muncul dan mengganggu pertumbuhan Jamur Tiram. Hal ini mengakibatkan banyak kerugian yang dialami oleh para petani dan pengusaha Jamur Tiram.

Berdasarkan permasalah diatas, maka peneliti ingin membuat sistem pakar berbasis web dengan judul "Sistem Pakar Diagnosa Hama dan Penyakit Pada Jamur Tiram Berbasis Web Menggunakan PHP dan Mysql" semoga dengan adanya sistem ini petani dapat membedakan jenis hama dan penyakit pada Jamur Tiram dan cara mengatasi masalah tersebut.

\section{Tinjauan Pustaka}

\subsection{Penelitian terkait}

Berikut ini merupakan beberapa penelitian terkait dalam penelitian ini,diantaranya :

1) Penelitian yang dilakukan oleh Nurjahratun (Fakultas Teknik Universitas Hamzanwadi tahun 2019) dengan judul sistem pakar diagnosa hama dan penyakit tanaman cabai merah besar berbasis web menggunakan metode forward chaining. Penelitian ini dilakukan di Desa Sembalun Lombok Timur pada sekelompok petani cabai merah besar. Adapun tujuan penelitian ini adalah untuk mengatasi permasalah para petani cabai merah besar di desa sembalun yang seringkali mengalami kegagalan panen disebabkan iklim atau perubahan cuaca ekstrim yang pada akhirnya menimbulkan hama dan penyakit pada tanaman cabai tersebut. Forward Chaining merupakan metode yang digunakan untuk mengatasi permasalahan para petani dengan cara melacak informasi yang ada serta dengan penggabungan rule sehingga menghasilkan sebuah kesimpulan dan pelacakan ini sangat baik karena prosesnya yang berjalan dikerjakan secara berurutan dari awal hingga ke akhir masalah serta mampu mendeteksi jenis penyakit dengan metode ranut maju dan dapat memberikan informasi pengobatan melalui pestisida, fungisida dan sebagainya.[9]

2) Penelitian yang dilakukan oleh Zul Asfi Waraehanun (Fakultas Teknik Universitas Hamzanwadi tahun 2019) dengan judul sistem pakar diagnosa penyakit gigi dan mulut berbasis web pada puskesmas Selong Lombok Timur. Kurangnya informasi serta rendahnya pengetahuan masyarakat tentang perlunya menjaga kesehatan gigi dan mulut dapat menimbulkan masalah. Untuk itu dibutuhkan suatu system yang dapat engatasi permasalahn mereka. Adapun tujuan penelitian ini adalah untuk melihat sekaligus meneliti apakah pemeriksaan gigi dan mulut dilakukan secara berkala dan pasien juga mendapatkan informasi mengenai kesehatan gigi dan mulut dengan cepat dan tepat. System yang digunakan dalam penelitian ini adalah system pakar berbasis web dimana system ini 
menampilkan gejala dan penyebab terjadinya kerusakan gigi danmulut serta bagaimana proses pencegahan, dan pennganannya dengan cepat dan tepat.[9]

3) Penelitian yang dilakukan oleh Rizki nurrahman bugis mahasiswa Institut teknologi malang tahun 2019 dengan judul sistem pakar diagnosis hama dan penyakit pada tanaman kelapa menggunakan metode certainty factor berbasis website. Penelitian ini dilakukan untuk mendiagnosis hama dan penyakit pada tanaman kelapa dengan memanfaatkan sistem pakar. Sehingga bisa membantu para pelajar dan masyarakat umum. Penelitian ini dilakukan di Dinas Pertanian dan Kehutanan Kota Tual, dengan seorang pakar bernama Abdulrahman Bugis. Data yang didapatpun telah di konsultasikan langsung dengan pakar tersebut. Sistem pakar adalah suatu program komputer yang dirancang untuk mengambil keputusan seperti keputusan yang diambil oleh seorang pakar. Aplikasi sistem pakar ini menerapkan metode Certainty Factor (CF) untuk menghasilkan suatu kesimpulan dan juga sebagai metode perhitungan berdasarkan nilai gejala dari hasil wawancara dengan pakar. Dari hasil pengujian fungsional yang dilakukan pada web browser Google Chrome didapatkan hasil $88 \%$ aplikasi berjalan dengan baik.[10]

4) Penelitian ke-empat yang dilakukan oleh Bambang Hermanto dkk, (universitas Negeri Lampung tahun 2020) dengan judul sistem pakar diagnosis penyakit pada tanaman vanili menggunakan metode dempstershafer berbasis web. Metode ini digunakan untuk mengatasi permasalahan petani vanili terkait kendala pengembangan, pendeknya umur produksi dan mengatasi penyakit serta hama yang menyerang pohon vanili sehingga menimbulkan kerugian bagi para petani. Untuk itu petani vanili perlu adanya ahli spesialisasi pertanian terutama ahli tanaman vanili dalam pengambilan keputusan dan kesadaran petani dengan kemajuan teknologi terbaru merupakan hal yang langka, ketersediaan pakar atau ahli manusia yang sangat mahal dan belum tersedia merupakan salah satu kendala lain dalam budidaya vanili di Indonesia. Adapun hasil dalam penelitian ini setelah dilakukan pengujian dengan metode dempster -shafer berbasis web adalah dapat mendiagnosa penyakit pada tanaman vanlili berdasarkan gejala-gejala yang muncul. Sedangkan hasil pengujian kepakaran yang telah dilakukan dapat dikatakan bahwa sistem dapat mendiagnosis penyakit dengan sangat baik sesuai dengan hasil diagnosis yang dilakukan oleh pakar dengan total rata-rata keakurasian sebesar 99,50\%.[11]

5) Menurut Sudianto Aris dalam penelitiannya menyatakan bahwa penggunaan Web menjadi salah satu alternatif dalam melakukan promosi wisata secara cepat, hasil yang diperolehpun menjadi lebih membantu dalam pemberian informasi yang 
cepat dan akurat, manfaat yang dihasilkan menjadi lebih efektif dibanding dengan menggunakan media yang lain secara manual/ ceramah/ diskusi[12].

6) Penelitian terakhir yang dilakukan oleh Dimas Aditya dkk, (Fakultas Teknik Universitas Muhamadiyah Ponorogo tahun 2019). Kemajuan teknologi sangat berpengaruh dalam kehidupan manusia. salah satu pemanfaatan teknologi ini dirasakan para petani dalam mendapatkan informasi mengenai hama dan penyakit jamur tiram. seiring munculnya berbagai macam hama dan penyakit yang terdapat pada jamur tiram yang dipengaruhi oleh beberapa faktor utama antara lain: kondisi suhu, air, tanah, SDM (Sumber Daya Manusia), serta bibit jamur. oleh karena itu dibutuhkan aplikasi sistem latih budidaya jamur dengan berbasis android serta mengadopsi metode decision tree serta dirancang menggunakan tool Android Studio.hasil dari perancangan aplikasi ini adalah memudahkan user dalam mendiagnosa hama dan penyakit jamur tiram tanpa harus mendatangi seorang pakar secara langsung dan bisa diakses secara langsung untuk pengguna smartphone karena berbasis android.

\subsection{Landasan Teori}

\section{Pengertian Sistem Pakar}

Secara umum Sistem pakar (expert system) merupakan paket perangkat lunak atau program komputer yang ditujukan sebagai penyedia nasihat dan sarana bantu dalam memecahkan masalah dalam bidang-bidang spesialisasi tertentu seperti perekayasaan matematika, kedokteran, pendidikan dan sebagainya.[13]

Sedangkan menurut martin dan juga oxman, yang dimaksud dengan sistem pakar adalah sebuah sistem yang berbasis komputer yang menggunakan pengetahuan, fakta, dan juga teknik penalaran tertentu dalam memecahkan masalah, yang mana masalah tersebut adalah sebuah masalah yang biasanya dapat dipecahkan oleh seorang pakar di dalam bidang atau disiplin ilmu tertentu.

\section{Web}

Menurut Rohi Abdulloh (2015) web adalah Sekumpulan halaman yang terdiri dari beberapa halaman yang berisi informasi dalam bentuk data digital baik berupa text, gambar, video, audio, dan animasi lainnya yang disediakan melalui jalur koneksi internet.[14]

\section{Pengertian jamur tiram}

Jamur tiram adalah jamur kayu yang tumbuh berderet menyamping pada batang kayu lapuk. Jamur ini memiliki tubuh buah yang tumbuh mekar membentuk corong dangkal seperti kulit kerang (tiram). Tubuh buah jamur memiliki tudung (pileus) dan tangkai (stipe). Pileus berbentuk mirip cangkang tiram berukuran 5 - 15 $\mathrm{cm}$ dan permukaan bagian bawah berlapis-lapis seperti insang berwarna putih dan lunak. Sedangkan tangkai berukuran $2-6 \mathrm{~cm}$ yang 
mana menyangga tudung agak lateral (di bagian tepi) atau eksentris (agak ke tengah).[6]

Jamur tiram putih adalah salah satu jenis jamur kayu yang banyak di konsumsi oleh masyarakat dengan gizi yang baik, di dalamnya terkandung 9 asam amino esensial dengan kadar protein 19$35 \%$. Pertumbuhan dan perkembangan jamur sangat tergantung pada nutrisi yang tersedia pada media tanam. Untuk memenuhi kebutuhan nutrisi tersebut, pada media tanam ditambahkan dedak sebagai sumber nutrisi.[6]

\section{Pengertian Hama}

Menurut Djojosumarto (2008) hama tanaman adalah mahluk hidup penganggu berupa hewan yang umumnya dapat dilihat dengan mata telanjang. Hama merusak tanaman dengan berbagai cara misalnya dengan memakan daun, melubangi dan membuat korok-korok pada batang, melubangi dan membuat korok-korok pada daun, mengisap cairan tanaman, dan memakan bunga dan bagian-bagian bunga dan sebagian.[15]

Adapun beberapa penyebab terjadinya hama pada tanaman antara lain peubahan tempat, perubahan lingkungan serta aplikasi pestisida yang tidak bijaksana dan berlebihan.

\subsection{Tahapan Penelitian}

Adapun tahapan dalam penelitian ini adalah digambarkan menggunakan diagram alir data / flowmap. Berikut tahapan penelitian yang diusulkan.[15]
Tabel 1. Model Tahap Penelitian

System pakar diagnosa penyakit jamur tiram berbasis WEB

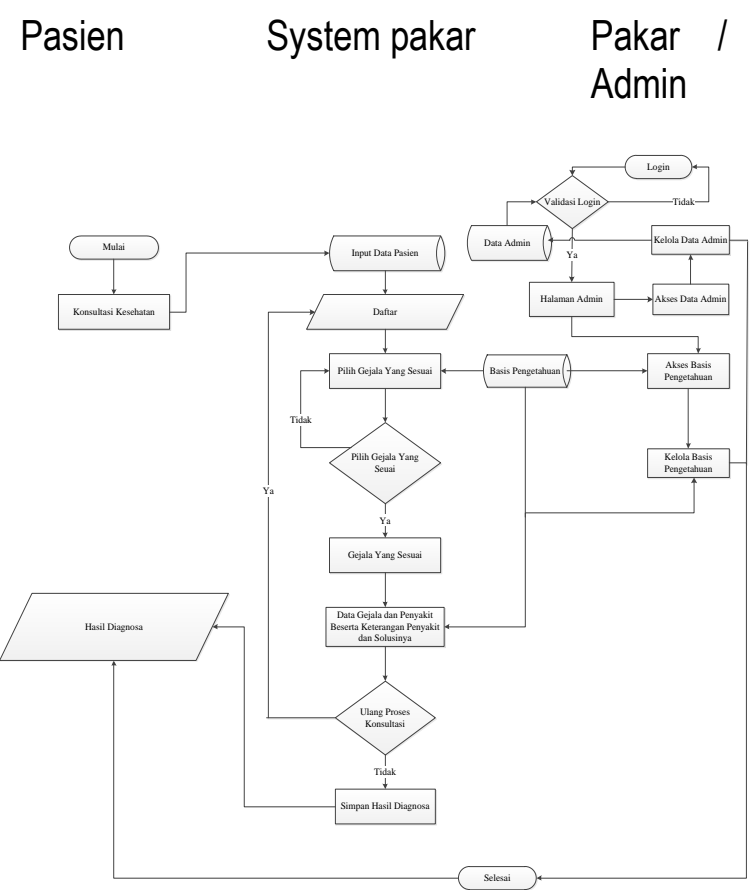

Populasi dan sampel dalam penelitian ini adalah kelompok petani jamur tiram Dasan Borok, Suralaga dan untuk sampel penelitian dilakukan pada salah satu petani yang melakukan penanaman sebanyak 1500 biji dan terjadi kegagalan panen yang disebabkan hama dan penyakit yang menyerang tanaman jamur tiram tersebut.

\section{Metode Penelitian}

\subsection{Teknik pengumpulan data}

Dalam penelitian ini adalah pertama observasi, digunakan untuk mengamati jamur tiram selama proses penanaman sampai panen. Kemudian teknik wawancara yaitu dengan melakukan wawancara langsung terhadap para petani jamur 
tersebut terkait masalah-masalah yang sering mereka alami. Terakhir studi pustaka, teknik ini dilakukan peneliti untuk mengumpulkan berbagai informasi terkait dengan teori-tori yang dibutuhkan untuk menambah pengetahuan dan waawasan peneliti tentang topik dan masalah yang dialami. [16]

\subsection{Lokasi penelitian}

Lokasi Penelitian ini dilakukan di Dusun Borok Kecamatan Suralaga Kabupaten Lombok Timur Nusa Tenggara Barat.

\section{Hasil dan Pembahasan.}

Dibawah ini adalah tampilan utama saat masuk ke menu data penyakit. Pakar dapat melihat seluruh data penyakit dan juga bisa mencari data, menambah data, mengedit dan mendelet data untuk lebih jelas dapat dilihat seperti gambar dibawah ini :

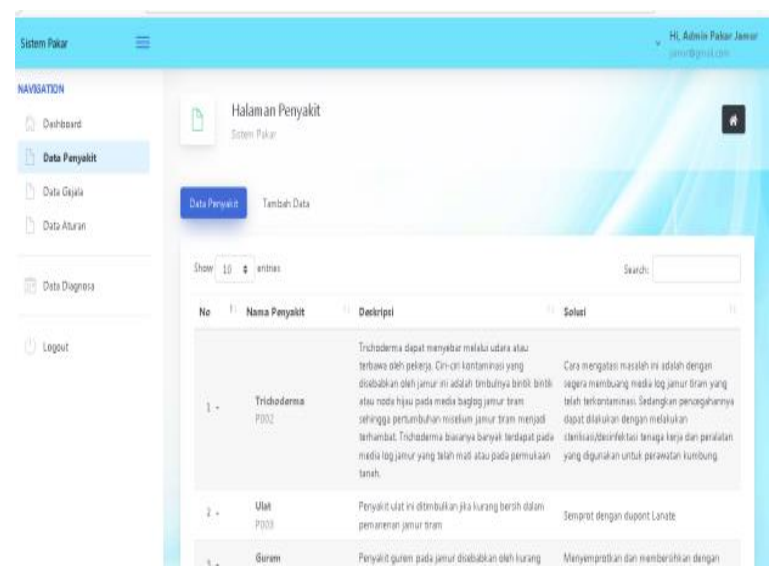

Gambar 1. Form Data Penyakit

Menu cari data penyakit merupakan halaman dimana pakar dapat mencari nama penyakit yang sudah di input oleh admin atau pakar misalnya jika kita ingin mencari penyakit yang nama penyakitnya "lalat kecil", maka yang keluar semua penyakit yang bernama "lalat kecil" saja, bentuk dari tampilan form cari data penyakit dapat dilihat seperti gambar dibawah ini

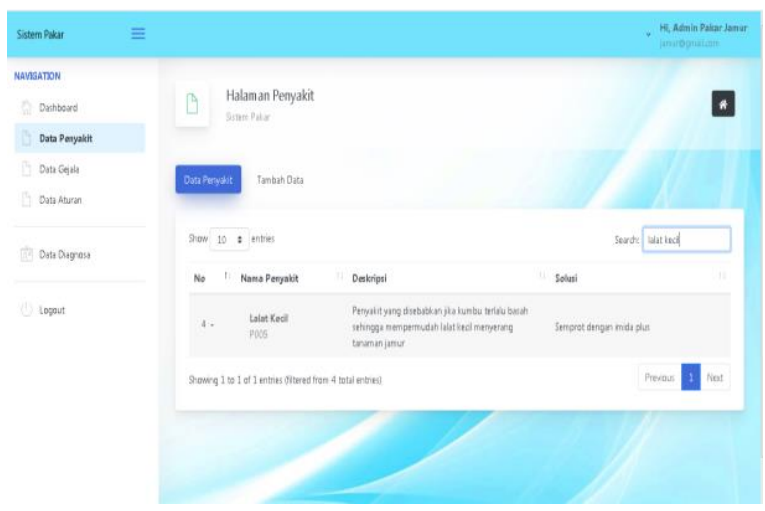

Gambar 2. Form Cari data Penyakit

Menu data diagnosa ini merupakan data laporan yang masuk jika petani jamur telah melakukan konsultasi, semua data petani beserta hasil diagnosa dapat disimpan di data diagnosa.

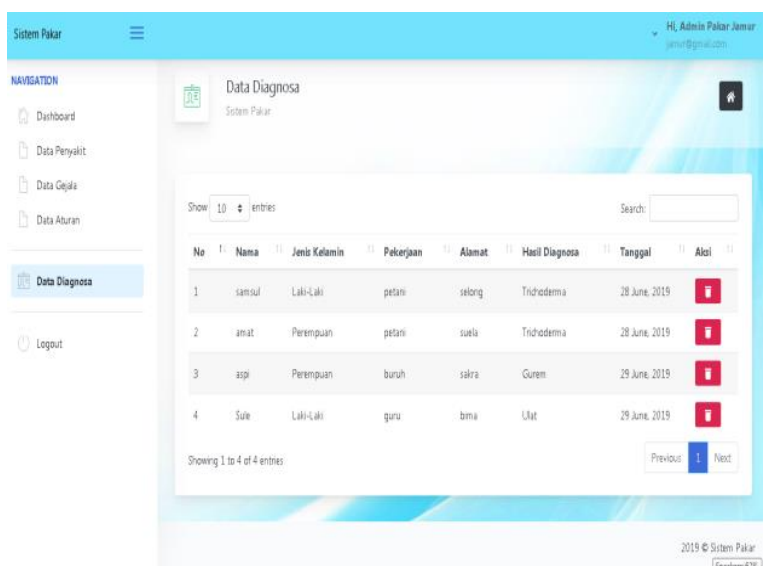

Gambar 3. Form Data Diagnosa

\section{Kesimpulan}

Berdasarkan hasil penelitian yang dilakukan maka didapatkan kesimpulan dimana dengan adanya sistem pakar berbasis web ini pembudidaya jamur tiram di Desa Suralaga dapat dengan mudah mendapatkan informasi serta mengerti faktor apa saja yang menyebabkan terjadinya penyakit pada tanaman 
jamur tiram dan bagaimana menagani permasalahn tersebut dengan cepat dan tepat.

Serta mendapatkan informasi mengenai jenisjenis hama yang menyerang tanaman jamur tiram tersebut dan dapat diketahui bagaimana penangananya.[13]

\section{Daftar Pustaka}

[1] H. J. P. Marvin and Y. Bouzembrak, "A system approach towards prediction of food safety hazards: Impact of climate and agrichemical use on the occurrence of food safety hazards," Agric. Syst., vol. 178, no. November 2019, p. 102760 , 2020.

[2] J. M. Aguado, B. Almirante, E. Bouza, and O. Len, "Guidelines for the prevention of invasive mould diseases caused by filamentous fungi by the Spanish Society of Infectious Diseases and Clinical Microbiology ( SEIMC )," 2011.

[3] K. Blin, S. Shaw, Y. Tong, and T. Weber, "Designing sgRNAs for CRISPR-BEST base editing applications with CRISPyweb 2 . 0," Synth. Syst. Biotechnol., vol. 5, no. 2, pp. 99-102, 2020.

[4] S. Schade et al., "Computers , Environment and Urban Systems Aliens in Europe. An open approach to involve more people in invasive species detection," Comput. Environ. Urban Syst., vol. 78, no. August, p. 101384, 2019.

[5] M. Schut, J. Rodenburg, L. Klerkx, A. Van Ast, and L. Bastiaans, "Systems approaches to innovation in crop protection . A systematic literature review," Crop Prot., vol. 56, pp. 98-108, 2014.

[6] S. Oide and B. G. Turgeon, "Mycoscience Natural roles of nonribosomal peptide metabolites in fungi," Mycoscience, vol. 61, no. 3, pp. 101-110, 2020.

[7] S. M. Sudianto Aris, "Penerapan Media Pembelajaran Interaktif Pelajaran Bahasa Indonesia Berbasis Android Untuk Kelas Vii Madrasah Tsanawiyah Nahdlatul
Wathan Ketangga Sebagai Upaya Untuk Peningkatkan Minat Belajar Siswa," Infotek J. Inform. dan Teknol., vol. 2, no. 2, pp. 53-60, 2019.

[8] J. Jalkanen, K. Vierikko, and A. Moilanen, "Urban Forestry \& Urban Greening Spatial prioritization for urban Biodiversity Quality using biotope maps and expert opinion," Urban For. Urban Green., vol. 49, no. November 2019, p. 126586, 2020.

[9] "No Title," pp. 1-10, 2019.

[10] R. N. Bugis, F. T. Industri, and C. Factor, "SISTEM PAKAR DIAGNOSIS HAMA DAN PENYAKIT PADA TANAMAN KELAPA MENGGUNAKAN METODE CERTAINTY FACTOR BERBASIS Jika kita hanya menambahkan CF R1 dan R2 , kepastian kombinasinya akan lebih dari 1 memodifikasikan jumlah kepastian melalui penambahan faktor kepastian kedua dan mengakalinya ( 1 dikurangi faktor kepastian pertama ). Jadi , semakin besar CF pertama semakin kecil kepastian penambahan kedua . Tetapi faktor tambahan selalu menambahkan beberapa kepastian .," vol. 3, no. 1, pp. 284-289, 2019.

[11] B. Hermanto and A. Sudirman, "SISTEM PAKAR DIAGNOSIS PENYAKIT PADA TANAMAN VANILI MENGGUNAKAN METODE DEMPSTER-SHAFER," vol. 8, no. 1, pp. 91-102, 2020.

[12] Sudianto Aris, "Penerapan Website Sebagai Sarana Promosi Wisata Budaya pada Kabupaten Lombok Timur," Infotek J. Inform. dan Teknol., vol. 1Sudianto, no. 1, pp. 11-17, 2018.

[13] P. P. Vinayaka, S. Van Den Driesche, S. Janssen, and M. Frodl, "On-Chip Monitoring of $\mathrm{pH}$ Change in Agar-Gels During Fungi Growth by Integrating Impedance and Colorimetric Principles," Procedia Eng., vol. 87, pp. 373-376, 2014.

[14] R. Naclerio, I. J. Ansotegui, J. Bousquet, and G. W. Canonica, "International expert consensus on the management of allergic rhinitis ( AR ) aggravated by air pollutants Impact of air pollution on patients with AR: Current knowledge and future 
strategies," World Allergy Organ. J., vol. 13, no. 3, p. 100106, 2020.

[15] C. Pechsiri and R. Piriyakul, "Developing a Why - How Question Answering system on community web boards with a causality graph including procedural knowledge," Inf. Process. Agric., vol. 3, no. 1, pp. 36-53, 2016.
[16] L. Lange, B. Pilgaard, F. Herbst, P. Kamp, F. Gleason, and A. Gorm, "Origin of fungal biomass degrading enzymes: Evolution, diversity and function of enzymes of early lineage fungi," Fungal Biol. Rev., vol. 33, no. 1, pp. 82-97, 2018. 